\title{
Floor dust bacteria and fungi and their coexistence with PAHs in Jordanian indoor environments
}

\section{Al-Hunaiti, Afnan}

2017-12-01

Al-Hunaiti , A , Arar , S , Täubel , M , Wraith , D , Maragkidou, A , Hyvärinen , A \& Hussein , T 2017 , ' Floor dust bacteria and fungi and their coexistence with PAHs in Jordanian indoor pÿenvironments ' , The Science of the Total Environment , vol. 601602 , pp. 940-945 . https://doi.org/10.1016/j.scitotenv.2017.05.211, https://doi.org/10.1016/j.scitotenv.2017.05.211

http://hdl.handle.net/10138/307290

https://doi.org/10.1016/j.scitotenv.2017.05.211

cc_by_nc_nd

acceptedVersion

Downloaded from Helda, University of Helsinki institutional repository.

This is an electronic reprint of the original article.

This reprint may differ from the original in pagination and typographic detail.

Please cite the original version. 


\title{
Floor Dust Bacteria and Fungi and their Coexistence with PAHs in Jordanian Indoor Environments
}

\author{
Afnan Al-Hunaiti ${ }^{1}$, Sharif Arar ${ }^{2}$, Martin Täubel ${ }^{3}$, Darren Wraith ${ }^{4}$ \\ Androniki Maragkidou ${ }^{5}$, Anne Hyvärinen ${ }^{3}$, Tareq Hussein ${ }^{6(*)}$ \\ ${ }^{1}$ University of Petra, Department of Chemistry, Amman, Jordan \\ ${ }^{2}$ The University of Jordan, Department of Chemistry, Amman 11942, Jordan \\ ${ }^{3}$ National Institute for Health and Welfare (THL), Department of Health Protection Living Environment and \\ Health Unit, PL 95, FI-70701 Kuopio, Finland \\ ${ }^{4}$ Queensland University of Technology, Institute of Health and Biomedical Innovation (IHBI), Victoria Park \\ Road, Kelvin Grove, 4059, Queensland, Australia \\ ${ }^{5}$ University of Helsinki, Division of Atmospheric Sciences, PL 48, FI-00014, Helsinki, Finland \\ ${ }^{6}$ The University of Jordan, Department of Physics, Amman 11942, Jordan
}

\begin{abstract}
Floor dust samples were collected from Jordanian indoor environments (eight dwellings and an educational building) in Amman. Quantitative PCR (qPCR) analyses of selected fungal and bacterial groups were performed. The bacterial and fungal concentrations were also correlated with PAHs concentrations, which were previously measured in the same samples by using GC-MS. The bacterial and fungal concentrations varied significantly among and within the tested indoor environments. Based on the collected samples in the entrance area of the dwellings, the largest variation was found in Gram-negative bacteria and total fungi concentration. The lowest bacterial and fungal concentrations were found in the dwelling that was least occupied and the most recently built. At the educational building, the Gram-positive bacteria concentrations were lower than those observed in the dwellings. The biocontaminants showed a clear correlation with some polycyclic aromatic hydrocarbons (PAHs). This suggests that the tested indoor environments might be at high risk of exposure to PAHs metabolite. Since biocontamination in floor dust has been given relatively little to no attention in the MENA region we recommend that more extensive measurements be conducted in the future with chemical and biological analysis of floor dust contaminants and their exposure indoors.
\end{abstract}

Keywords: Gram-positive, Gram-negative, Penicillium/Aspergillus spp., Total fungi, Dwellings, Educational building.

${ }^{*}$ Corresponding author, Tel: +962-6-5355000; Fax: +962-6-5300253, e-mail address: t.hussein @ju.edu.jo 


\section{Introduction}

Pollution has been a general and common problem for a long time (e.g. Morawska et al., 2013). Exposure to pollution can occur via three main routes: dermal, inhalation, and ingestion causing health problems (e.g. Alam et al., 2014; Grimsley et al., 2012; Günther et al., 1998).

Particularly, household dust accommodates a vast range of biological contamination, which includes microbes (i.e. microorganisms such as fungi, bacteria, and viruses) and non-microbes (such as insects and their dry parts, dust-mites, and cells from humans, plants, and animals). In general, biological contamination have limited direct toxicity on humans but they are often involved in the etiology of building related illness that is either infective or allergic as well as resulting in decreased lung function, respiratory symptoms, asthma and rhinitis, and sick-building syndrome (e.g. Morawska et al., 2013; Mandal and Brandl, 2011; Ross et al., 2000).

The dynamic behavior of biological contamination in the indoor air and floor dust can be described mathematically by means of a material-balance equation (e.g. Bhangar et al., 2014; Nazaroff, 2014; Meadow et al., 2013; Nazaroff and Cass, 1989), which includes several terms to describe the controlling factors (sources and sinks) of the concentration change rate in both the air and the floor dust. The outdoor air concentration of any contaminant drives its concentration indoors via the indooroutdoor air exchange (i.e. ventilation rate) and the penetration factor (filtration and infiltration), which are the main building characteristics defining the indoor-to-outdoor relationship of air pollutants (e.g. Hussein et al., 2015; Hussein and Kulmala, 2008; Nazaroff, 2004). The production, survival, and decay of bacteria and fungi inside floor dust is affected by many factors: (1) their airborne concentrations, (2) building characteristics (e.g. ventilation, penetration, type of interior surfaces, etc.), (3) occupants and their activities, (4) environmental conditions, and (5) coexistence with chemical pollution (such as polycyclic aromatic hydrocarbons (PAHs) and volatile organic compounds (VOCs)).

It was reported that the fate of PAHs in soil is affected by various factors including biological diversity and abundance (Gupte et al., 2016; Semple et al., 2003; Reid et al., 2000; Heitkamp et al., 1988). Wood-decaying fungi can detoxify, oxidize, and transform PAH (e.g. Günther et al., 1998). A long time ago, it was also confirmed that some microbial metabolites of naphthalene occur in microcosms containing natural freshwater and estuarine sediments (Heitkamp et al., 1987). As an advantage, PAHs can be removed by using microbial and fungal degradation, which is a natural technique (e.g. Leitão, 2009; Johnsen et al., 2006; Munoz et al., 2003). 
In this study, the aim was to quantify fungal and bacterial concentrations inside floor dust samples collected from dwellings and an educational building in Amman, Jordan. We also applied simple statistical tests between the tested microbe concentrations and the PAHs concentrations.

\section{Materials and Methods}

\subsection{Floor dust samples}

Floor dust samples were collected during April 3-9, 2015 from eight dwellings and an education building located in Amman, Jordan (Figure 1). These indoor environments were naturally ventilated. The weather condition (T, RH, and precipitation) during this period is presented in Figure S1. The collection procedure of floor dust samples and detailed description about the dwellings and the education building can be found in our previous studies Maragkidou et al. (2016 and 2017). Here, we provide this information in brief.

Two samples were taken from each dwelling (living room and main entrance). In order to collect a reasonable amount of floor dust samples, the dwellings were not vacuum cleaned for 3-4 days before samples were collected. The type and age of each dwelling as well as the type and area of the floor are given in Table S1. The educational building was the Department of Physics of the University of Jordan (Table S2 and Figure S2). All samples were collected on the same day. The cleaning staff executed their routine daily cleaning activities normally. Although smoking was prohibited inside the university buildings, sometimes this was violated.

As described by Maragkidou et al. (2016 and 2017). The floor dust samples were collected by using a regular vacuum cleaner. We placed the vacuum dust bags made of nylon $(25 \mu \mathrm{m}, 155 \mathrm{~mm} \times 73 / 38$ $\mathrm{mm}$, Allied Filter Fabrics Pty. Ltd) inside the tube of the vacuum cleaner. Each sample was collected from 3 minutes of vacuum cleaning and a floor surface area as listed in Tables S1 and S2. Immediately after dust collection, the dust bags were closed and put inside a zipped plastic bag. Each dust sample was then put in a glass vial, wrapped with aluminum foil and stored in the freezer $\left(-20{ }^{\circ} \mathrm{C}\right)$. Shipment to the laboratory was undertaken at room temperature and samples were stored in the laboratory at $20{ }^{\circ} \mathrm{C}$ until analyses were completed.

\subsection{Biological analysis}

DNA was extracted from weighted samples of dusts of approximately $20 \mathrm{mg}$ using Chemagic DNA Plant kit (PerkinElmer chemagen Technologie GmbH, Germany) on KingFisher mL magnetic bead based DNA extraction robot (Thermo Scientific, Finland). In an initial step, microbial cells were disrupted with bead-beating as described in (Kärkkäinen et al. 2010), using MiniBeadBeater-16 
(Biospec Products Inc). Salmon tests DNA (Sigma Aldrich, USA) was added as an internal standard to the samples prior to DNA extraction (Haugland et al. 2012) to account for PCR inhibitors and variability in DNA extraction efficiency.

Quantiative PCR (qPCR) analyses of selected fungal and bacterial groups and calculations of cell equivalents per mg of dust were performed as described by Kaarakainen et al. (2009). qPCR assays used in this study have been published previously as follows: total fungal DNA (Haugland \& Vesper, US pat. 2002; 6387 652), group of Aspergillus spp./Penicillium spp./Paecilomyces variotii (Haugland et al. 2004), and Gram-positive and Gram-negative bacteria (Kärkkäinen et al. 2010). QPCR reactions were performed as written in the original publications with minor modifications. In the bacterial duplex assay $20 \mu 1$ reaction mix included $10 \mu \mathrm{l}$ of Environmental Master Mix (Applied Biosystems Inc., Foster City, CA), $1.5 \mu$ l Bovine serum albumin $(2 \mathrm{mg} / \mathrm{ml}), 1 \mu \mathrm{l}$ of forward and reverse primers, $0.4 \mu \mathrm{l}$ of a both TaqMan probes, $3.7 \mu 1$ of nuclease free water (HyClone Laboratories Inc., Utah, USA) and $2 \mu 1$ of template DNA. The analysis was performed on Stratagene Mx3005P QPCR System (Agilent Technologies Inc., USA) equipment.

\subsection{Polycyclic aromatic hydrocarbons (PAHs)}

The polycyclic aromatic hydrocarbons (PAHs) concentrations were previously investigated by Maragkidou et al. (2016) for the dwellings and by Maragkidou et al. (2017) for the educational building (Tables S3 and S4). The PAHs concentrations were quantified via GC-EI/MS.

\section{Results and discussion}

\subsection{Bacterial and fungal contamination}

The bacterial and fungal concentrations in the dwellings varied significantly in both the entrance and living room (Table S5 and Figure 2). The Gram-positive bacteria concentrations in the entrance were 17700-95800 CE/mg (excluding the extreme value at A3, 348300 CE/mg) and the Gram-negative bacteria were 8900-2254300 CE/mg. As for Penicillium/Aspergillus spp., it was in the range 200$7300 \mathrm{CE} / \mathrm{mg}$ and total fungi concentrations were 500-35100 CE/mg (excluding the extreme value at $\mathrm{A} 2, \sim 172300 \mathrm{CE} / \mathrm{mg}$ ). As for tha the living room, the Gram-positive bacteria concentrations were 11300-265400 CE/mg (excluding the extreme value at A3, 959100 CE/mg) and the Gram-negative bacteria were 20700-423000 CE/mg. As for Penicillium/Aspergillus spp., it was in the range 600$26400 \mathrm{CE} / \mathrm{mg}$ and total fungi concentrations were 600-7700 CE/mg (excluding the extreme value at DH3, 30200 CE/mg). Dwelling A4, which was the least occupied and the most recently built, had the lowest concentrations of fungi and Gram-negative bacteria in both the entrance and living room. 
It also had the lowest Gram-positive bacteria concentrations in the living room whereas dwelling DH4 had the lowest Gram-positive bacteria concentrations in the entrance.

At the educational building, the Gram-positive bacteria concentrations (5300-136000 CE/mg) and Penicillium/Aspergillus spp. concentrations (200-5100 CE/mg) were lower than those observed in the dwellings (Tables S5 and S6 and Figures 2 and 3). As for the Gram-negative bacteria, the concentrations at the education building (38700-495000 CE/mg) were higher than those observed at the dwellings. The total fungi concentrations at the educational building (800-10700 CE/mg) were in the same range as those in the dwellings. Both corridors ( $\mathrm{BC}$ and $\mathrm{C} 1)$ had the highest concentrations of Gram-positive bacteria whereas the workshop had the lowest concentrations. All offices, lecture rooms, and the corridors had Gram-negative concentrations higher than $1 \times 10^{5} \mathrm{CE} / \mathrm{mg}$ whereas the workshop had concentrations less than $1 \times 10^{5} \mathrm{CE} / \mathrm{mg}$. The main corridor/first floor $(\mathrm{C} 1)$ had the lowest Penicillium/Aspergillus spp. concentration whereas the workshop welding area had the highest concentration. The big corridor (BC) located at the main entrance/ground floor had the highest total fungi concentration whereas the welding area at the workshop had the lowest concentration.

Tischer et al. (2015) reported Penicillium/Aspergillus spp. as well as Gram-positive and Gramnegative bacteria concentrations inside houses in Europe. When compared to this study, Penicillium/Aspergillus spp. and Gram-positive bacteria were lower compared to most European countries, but Gram-negative bacteria concentrations appeared to be rather high. This could indicate that human source derived mostly Gram-positive bacteria are somewhat less in Jordan dwelling dust, and Gram-negative bacteria from mostly environmental sources - hypothetically - are more dominant. This is hypothetical though as we were limited by the number of samples taken and without identification of the bacteria with e.g. NGS.

The differences in bacterial and fungal concentrations amongst the studied indoor environments in this study indicate that sources of biocontamination are different in different locations of the city. Adams et al. (2014) confirmed that indoor fungi and bacteria that are originated from outdoor sources vary in space and time, which relates to environmental conditions as being major factors affecting the concentrations of biological content of indoor floor dust. Weikl et al. (2016) made it evident that indoor fungi are more affected than bacteria by certain environmental conditions such as vegetation, urbanization, and outdoor particulate matter. For example, fungal communities in indoor dust changed semi-annually whereas bacterial communities followed outdoor plant phenological periods. The small variations in gram- positive bacteria indoors could be attributed to the positive strains tolerance to dry conditions which manage them to grow without the presence of mold in contrary to negative- bacteria (Adhikari et al., 2014). 
Also, it is well known that humans' activities are major sources of bacteria; in particular, Grampositive bacteria, in house dust (e.g. Meadow et al., 2013; Täubel et al., 2009; Goh et al., 2000). This was primarily attributed to increased human shedding of skin cells, ejection of microorganisms and particulates from the respiratory tract, and the transport of bacteria on suspended dust particles from floor surfaces. Several other studies have also confirmed that occupancy and occupants' activities increased bacterial concentrations indoors (e.g. Weikl et al., 2016; Bhangar et al., 2014; Meadow et al., 2013). Unfortunately, the source origin (as indoors or outdoors) of bacteria and fungi inside the dwellings was not able to be identified in our study due to a lack of information about occupancy and activities, building characteristics, and environmental conditions. Further investigation on this is needed in the future.

In addition to occupancy and outdoor sources, environmental conditions (e.g. temperature, relative humidity, moldiness, etc.) might also be a driving factor for increasing concentrations of bacteria and fungi indoors. Goh et al. (2000) showed that the concentration of fungal spores inside a library was fifty times lower than outdoors due to a lower relative humidity indoors. Grimsley et al. (2012) showed that rain and flooding caused by Hurricane Katrina in the U.S resulted in widespread growth of mold and bacteria indoors.

Among building characteristic, floor type is a very important factor for the survival of biological contamination. Foarde and Berry (2004) illustrated that carpet flooring was not a major contributor to airborne concentrations of biocontaminants in two schools. They also showed that carpeted surfaces have higher surface loadings of the biocontaminants. On the other hand, airborne concentrations were significantly higher over tiled floors, possibly linking to better resuspension of floor dust on tiled flooring.

Biological contamination in floor dust has not been given enough attention in the Middle East and North Africa (MENA). Ali et al. (2014) investigated the bacteriological quality of water and carpets inside mosques in Elkhomes city in Libya; they suggested that mosques, as communal environments, may play a role in the spread of multidrug-resistant bacteria in the community and pose a serious health risk to worshipers in case the carpets are not treated against microbe contamination. We also found three studies conducted in Egypt and another in Iran, but they all considered bioaerosols.

\subsection{Correlations between bacteria, fungi and PAHs concentrations}

We examined Spearmans rank correlation coefficient between the biological contamination (bacterial and fungal concentrations) and PAHs concentrations. The statistical sample size for each type of dwelling was too small to enable reliable estimates separately for different areas of the building or type of dwelling; therefore, we applied the analysis for all samples combined (Table S7). 
Gram-positive bacteria had a reasonably moderate positive correlation with phenanthrene only whereas Gram-negative bacteria had significant positive correlation with fluoranthene and pyrene only. Biodegradation of PAHs containing more than three aromatic rings is not very well understood because of their large size and extreme insolubility; fluoranthene and pyrene are examples of such PAHs (Mrozik et al., 2003). Interestingly, mycobacteria have been repeatedly isolated as bacteria that can degrade pyrene and benzo[a]pyrene. Although these bacteria are known for their comparatively slow growth, their growth on PAHs is faster than other bacteria (Mrozik et al., 2003).

Penicillium/Aspergillus spp had a moderate to strong negative correlations with anthracene, fluoranthene, benzo(b)fluoranthene, and benzo(j)fluoranthene. Total fungi showed significant negative correlations with anthracene, benz(a)anthracene, and dibenz(a-h)anthracene. Maigari et al. (2015) explained that Penicillium/Aspergillus spp, which are non-ligninolytic fungi, uses cytochrome $\mathrm{P}_{450}$-mediated oxidation mechanism. This was tested to have the tendency and ability to degrade or metabolite anthracene, fluoranthene, benzo(b)fluoranthene, and benzo(j)fluoranthene. Total fungi includes all types (non-ligninolytic and ligninolytic). Linginolytic fungi utilize different metabolic pathways but they can degrade a wide range of PAHs (Maigari et al., 2015).

In general, many studies have shown that bacteria and fungi metabolite PAHs (e.g. Gupte et al., 2016; Munoz et al., 2003; Semple et al., 2003; Reid et al., 2000; Heitkamp et al., 1987 and 1988). They transform PAHs to activated products such as diol-oxides (PAHs metabolites by the cytochrome P450 or similar mechanisms). This is expected to have increased health risk from the exposure to PAHs activated products diol-oxides that mutate humans' DNA and RNA (e.g. Igwe and Ukaogo, 2015; Skupinska et al., 2004; IARC 1983).

\section{Conclusion}

The bacterial and fungal concentrations varied significantly among and within the studied indoor environments. This variation indicates that indoor and outdoor sources are different in different locations of the city. The lowest bacterial and fungal concentrations were found in the dwelling that was least occupied and the most recently built.

The bacterial and fungal concentrations showed clear correlations with some PAHs concentrations. The Gram-positive bacteria had a reasonably moderate positive correlation with phenanthrene whereas Gram-negative bacteria had significant positive correlations with fluoranthene and pyrene. Penicillium/Aspergillus spp. had moderate to strong negative correlations with anthracene, fluoranthene, benzo(b)fluoranthene, and benzo(j)fluoranthene. Total fungi concentration showed significant negative correlations with anthracene, benz(a)anthracene, and dibenz(a-h)anthracene. 
This means that occupants in such indoor environments are at high risk of exposure to PAHs metabolite, which are active and carcinogenic products.

It is expected that exposure to PAHs metabolites (e.g. by the cytochrome P-450 or similar mechanisms) might have increased health risk for humans and indoor pets. For instance, it might mutate humans' DNA and RNA.

Since biocontamination in floor dust has been given relatively little attention in the MENA region we recommend that more extensive measurements be conducted in the future with chemical and biological analysis of floor dust contaminants and their exposure indoors.

\section{Acknowledgements}

This study was supported by the Deanship of Academic Research at the University of Jordan, University of Petra, the European Commission (FP7-PEOPLE-2012-ITN) Marie Curie ITN (HEXACOMM, project no. 315760), and the Academy of Finland Center of Excellence (grant no. 272041).

\section{References}

Adhikari, A., Kettleson, E.M., Vesper, S., Kumar, S., Popham, D.L., Schaffer, C., Indugula, R., Chatterjee, K., Allam, K.K., Grinshpun, S.A., Reponen, T., 2014. Dustborne and airborne Gram-positive and Gram-negative bacteria in high versus low ERMI homes. Sci. Total Environ. 482-483, 92-99.

Alam, M.J., Anu, A., Walk, S.T., Garey, K.W., 2014. Investigation of potentially pathogenic Clostridium difficile contamination in household environs. Anaerobe 27, 31-33.

Ali, M.M.M., Alemary, F., Alrtail, A., Rzeg, M.M., Albakush, A.M., Ghenghesh, K.S., 2014. High isolation rates of multidrug-resistant bacteria from water and carpets of mosques. Libyan $\mathrm{J}$. Med. 9, 25415-2518.

Bhangar, S., Huffman, J.A., Nazaroff, W.W., 2014. Size-resolved fluorescent biological aerosol particle concentrations and occupant emissions in a university classroom. Indoor Air 24, 604617.

Cerniglia, C. E. 1984. Microbal metabolism of polycyclic aromatic hydrocarbons. Adv. Appl. Microbiol. 30, 31-71.

Foarde, K., Berry, M., 2004. Comparison of biocontaminant levels associated with hard vs. carpet floors in nonproblem schools: results of a year long study. J. Expo. Anal Environ. Epidemiol. 14, Suppl 1, 41-48.

Goh, I., Obbard, J.P., Viswanathan, S., Huangy, Y., 2000. Airborne bacteria and fungal spores in the indoor environment. A case study in Singapore. Acta Biotechnol. 20, 67-73.

Grimsley, L. F., Chulada, P. C., Kennedy, S., White, L., Wildfire, J., Cohn, R.D., Mitchell, H., Thornton, E., El-Dahr, J., Mvula, M.M., Sterling, Y., Martin, W.J., Stephens, K.U., Lichtveld M., 2012. Indoor environmental exposures for children with asthma enrolled in the HEAL Study, Post-Katrina New Orleans. Environ. Health Perspect. 120, 1600-1606. 
Gupte, A., Tripathi, A., Patel, H., Rudakiya, D., Gupte, S., 2016. Bioremediation of Polycyclic Aromatic Hydrocarbon (PAHs): A Perspective. The Open Biotechnology Journal 10 (Suppl-2, M9), 363-378.

Günther, T., Sack, U., Hofrichter, M., Lätz, M., 1998. Oxidation of PAH and PAH-derivatives by fungal and plant oxidoreductases. J. Basic Microbiol. 38, 113-122.

Haugland, R.A., Siefring, S., Lavender, J., Varma, M., 2012. Influences of sample interference and interference controls on quantification of enterococci fecal indicator bacteria in surface water samples by the qPCR method. Water Research 46, 5989-6001.

Haugland, R.A., Varma, M., Wymer, L.J., Vesper, S.J., 2004. Quantitative PCR analysis of selected Aspergillus, Penicillium and Paecilomyces species. Syst. Appl.Microbiol. 27, 198-210.

Heitkamp, M. A., Franklin, W., Cerniglia, C. E., 1988. Microbial Metabolism of Polycyclic Aromatic Hydrocarbons: Isolation and Characterization of a Pyrene-Degrading Bacterium. App. Environ. Microbiol. 54, 2549-2555.

Heitkamp, M. A., Freeman, J. P., Cerniglia, C. E., 1987. Naphthalene biodegradation in environmental microcosms: estimates of degradation rates and characterization of metabolites. Appl. Environ. Microbiol. 53,129-136.

Hussein, T., Kulmala, M., 2008. Indoor aerosol modeling: basic principles and practical applications. Water Air Soil poll. Focus 8, 23-34.

Hussein, T., Wierzbicka, A., Löndahl, J., Lazaridis, M., Hänninen, O., 2015. Indoor Aerosol Modeling for Assessment of Exposure and Respiratory Tract Deposited Dose. Atmos. Environ. 106, 402-411.

Igwe, J. C., Ukaogo, P. O., 2015. Environmental Effects of Polycyclic Aromatic Hydrocarbons. J. Natural Sci. Res. 5,117 - 131.

International Agency for Research on Cancer (IARC), 1983. Polynuclear Aromatic Compounds, Part 1, Chemical, Environmental and Experimental Data, IARC Monographs on the Evaluation of the Carcinogenic Risk of Chemicals to Humans, Vol. 32, Lyon, France, pp. 33-91.

Jacobs, J., Borràs-Santos, A., Krop, E., Täubel, M., Leppänen, H., Haverinen-Shaughnessy, U., Pekkanen, J., Hyvärinen, A., Doekes, G., Zock, J.-P., Heederik, D. 2014. Dampness, bacterial and fungal components in dust in primary schools and respiratory health in schoolchildren across Europe. Occup. Environ. Med. 71,704-712.

Johnsen, A. R., de Lipthay, J. R., Sørensen, S. J., Ekelund, F., Christensen, P., Andersen, O., Karlson, U., Jacobsen, C. S. 2006. Microbial degradation of street dust polycyclic aromatic hydrocarbons in microcosms simulating diffuse pollution of urban soil. Environ. Microbiol. 8, 535-545.

Kaarakainen, P., Rintala, H., Vepsalainen, A., Hyvarinen, A., Nevalainen, A., Meklin, T., 2009. Microbial content of house dust samples determined with qPCR. Sci. Total Environ. 407, 46734680 .

Kärkkäinen, P.M., Valkonen, M., Hyvarinen, A., Nevalainen, A., Rintala, H., 2010. Determination of bacterial load in house dust using qPCR, chemical markers and culture. J. Environ. Monit. $12,759-68$.

Leitão, A. L., 2009. Review: Potential of Penicillium Species in the Bioremediation Field. Int. J. Environ. Res. Public Health 6, 1393-1417.

Mandal, J., Brandl, H., 2011. Bioaerosols in indoor environment - A review with special reference to residential and occupational locations. Open Environ. Biol. Monit. J. 4, 83-96.

Maragkidou, A., Arar, S., Al-Hunaiti, A., Ma, Y., Harrad, S., Jaghbeir, O., Faouri, D., Hämeri, K., Hussein, T., 2016. Occupational health risk assessment and exposure to floor dust PAHs inside an educational building. Sci. Total Environ. (in press, http://dx.doi.org/10.1016/j.scitotenv.2016.11.055). 
Maragkidou, A., Ma, Y., Jaghbeir, O., Faouri, D., Harrad, S., Al-Hunaiti, A., Arar, S., Hameri, K., Hussein, T., 2016. PAHs in household floor dust collected in Amman, Jordan. J. Chem. Eng. Process Technol. 7:292.

Meadow, J.F., Altrichter, A.E., Kembel, S.W., Kline, J., Mhuireach, G., Moriyama, M., Northcutt, D., O'Connor, T.K., Womack, A.M., Brown, G.Z., Green, J.L., Bohannan, B.J., 2014. Indoor airborne bacterial communities are influenced by ventilation, occupancy, and outdoor air source. Indoor Air 24, 41-48.

Morawska, L., Afshari, A., Bae, G.N., Buonanno, G., Chao, C.Y., Hänninen, O., Hofmann, W., Isaxon, C., Jayaratne, E.R., Pasanen, P., Salthammer, T., Waring, M., Wierzbicka, A., 2013. Indoor aerosols: from personal exposure to risk assessment. Indoor Air 23, 462-487.

Mrozik, A., Seget, P.T., Lubuzek, S., 2003. Bacterial degradation and bioremediation of polycyclic aromatic hydrocarbons. Polish Journal of Environmental Studies 12, 15-25.

Muñoz, R., Guieysse, B., Mattiasson, B., 2003. Phenanthrene biodegradation by an algal-bacterial consortium in two-phase partitioning bioreactors. Appl. Microbiol. Biotechnol. 61, 261-267.

Nazaroff, W.W., 2004. Indoor particle dynamics. Indoor Air Suppl 7, 175-183.

Nazaroff, W.W., 2016. Indoor bioaerosol dynamics. Indoor Air 26, 61-78.

Nazaroff, W. W., Cass, G. R. 1989. Mathematical Modeling of Indoor Aerosol Dynamics. Environmental Science and Technology 23, 157-166.

Reid, B. J., Jones, K. C., Semple, K. T., 2000. Bioavailability of persistent organic pollutants in soils and sedimentsa perspective on mechanisms, consequences and assessment. Environ. Pollut. 108, 103-12.

Ross, M. A., Curtis, L., Scheff, P. A., Hryhorczuk, D. O., Ramakrishnan, V., Wadden, R. A., and Persky, V. W., 2000. Association of asthma symptoms and severity with indoor bioaerosols. All. 55, 705-711.

Semple, K. T., Morriss, A. W., Paton, G. I., 2003. Bioavailability of hydrophobic organic contaminants in soils: fundamental concepts and techniques for analysis. Eur. J. Soil. Sci. 54, 809-18.

Skupinska, K., Misiewicz, I., Kasprzycka-Guttman, T., 2004. Polycyclic aromatic hydrocarbons: physicochemical properties, environmental appearance and impact on living organisms. Acta Poloniae Pharmaceutica - Drug Research 61, 233-240.

Tischer, C., Zock, J.-P., Valkonen, M., Doekes, G., Guerra, S., Heederik, D., Jarvis, D., Norbäck, D., Olivieri, M., Sunyer, J., Svanes, C., Täubel, M., Thiering, E., Verlato, G., Hyvärinen, A., Heinrich, J. 2015. Predictors of microbial agents in dust and respiratory health in the Ecrhs. BMC Pulmonary Medicine 48.

Täubel, M., Rintala, H., Pitkäranta, M., Paulin, L., Laitinen, S., Pekkanen, J., Hyvärinen, A., Nevalainen, A., 2009. The occupant as a source of house dust bacteria. J. Allergy Clin. Immunol. 124, 834-839.

Weikl, F., Tischer, C., Probst, A.J., Heinrich, J., Markevych, I., Jochner, S., Pritsch, K., 2016. Fungal and bacterial communities in indoor dust follow different environmental determinants. PLoS ONE 11, e0154131. 


\section{Figures captions}

Figure 1: A map of Amman with site locations of the dwellings marked with yellow landmarks (abbreviations as listed in Table S1) and the campus of the University of Jordan (marked with red, see also Figure S2 and Table S2).

Figure 2: Bacterial and fungal concentrations in the floor dust samples collected at the dwellings: (upper) entrance area and (lower) living room area. The abbreviations: G. +ve, G.-ve, P.Asp., and Fung refer to Gram-positive bacteria, Gram-negative bacteria, Penicillium/Aspergillus spp., and total fungi; respectively.

Figure 3: Bacterial and fungal concentrations in the floor dust samples collected at the educational building. The abbreviations: G.+ve, G.-ve, P.Asp., and Fung refer to Gram-positive bacteria, Gram-negative bacteria, Penicillium/Aspergillus spp., and total fungi; respectively. 


\title{
Supplementary Information
}

\section{"Floor Dust Bacteria and Fungi and their Coexistence with PAHs in Jordanian Indoor Environments"}

\author{
Afnan Al-Hunaiti, Sharif Arar, Martin Täubel, Darren Wraith \\ Androniki Maragkidou, Anne Hyvärinen, Tareq Hussein
}

Table S1: Features of the dwellings and floor, where the dust samples were collected.

\begin{tabular}{|c|c|c|c|c|c|c|}
\hline Code & $\begin{array}{c}\text { Age } \\
{[\text { years }]}\end{array}$ & Type & $\begin{array}{c}\text { Level in } \\
\text { Building }\end{array}$ & $\begin{array}{c}\text { Location in } \\
\text { Dwelling }\end{array}$ & Area $\left[\mathbf{m}^{2}\right]$, Type & Date \\
\hline DH2 & 10 & Detached House & $2^{\text {nd }}$ floor & Entrance & $0.75 \times 0.50$, carpet & April 3 \\
\hline & & & & Living room & $1.00 \times 1.00$, carpet & \\
\hline A2 & 5 & Apartment & $2^{\text {nd }}$ floor & Entrance & $0.91 \times 0.60$, carpet & April 3 \\
\hline & & & & Living room & $1.00 \times 1.00$, carpet & \\
\hline DH3 & 30 & Detached House & Ground floor & Entrance (inside) & $2.00 \times 2.00$, carpet & April 3 \\
\hline & & & & Living room & $2.00 \times 2.00$, carpet & \\
\hline DH4 & 15 & Detached House & Ground floor & Entrance (inside) & $0.60 \times 0.60$, carpet & April 5 \\
\hline & & & & Living room & $2.00 \times 2.00$, carpet & \\
\hline A3 & 4 & Apartment & $1^{\text {st }}$ floor & Entrance (inside) & $1.00 \times 0.50$, carpet & April 5 \\
\hline & & & & Living room & $2.00 \times 2.00$, carpet & \\
\hline A4 & 3 & Apartment & $2^{\text {nd }}$ floor & Entrance (inside) & $2.00 \times 2.00$, ceramic tiles & April 3 \\
\hline & & & & Living room & $2.00 \times 2.00$, carpet & \\
\hline DH5 & 40 & Detached House & Ground floor & Entrance (inside) & $2.00 \times 2.00$, carpet & April 3 \\
\hline & & & & Living room & $2.00 \times 2.00$, carpet & \\
\hline H & 10 & House & Ground floor & Entrance & $1.00 \times 1.00$, ceramic tiles & April 9 \\
\hline & & & & Living room & $2.00 \times 2.00$, ceramic tiles & \\
\hline
\end{tabular}

Note: In this study, an "apartment" is a dwelling in an apartment building that shares the main entrance of the building and some common areas around the building (such as parking and roof). A "house" is built on its own separate land. A "detached house" is an apartment in the ground floor of an apartment building but it has its own entrance and facilities; in that sense, it is like a house in living style but similar to apartments in structure. 
Table S2: A summary about the rooms and floor surfaces from which the dust samples were collected at the Department of Physics, the University of Jordan. Samples were collected on April 29, 2015. The bare floor tiles used in the building was made cement filled with small marble stones.

\begin{tabular}{|l|l|l|c|c|}
\hline & & & Surface area $\left[\mathrm{m}^{2}\right]$ & Surface type \\
\hline P200 & Office 200 & 1st floor & $1.50 \times 1.50$ & Carpet \\
\hline P209 & Office 209 & 1st floor & $3.00 \times 3.00$ & Bare floor \\
\hline P300 & Office 300 & 2nd floor & $3.00 \times 1.00$ & Carpet \\
\hline P303 & Office 303 & 2nd floor & $1.50 \times 1.50$ & Carpet \\
\hline L230 & Lecture room 230 & 1st floor & $2.70 \times 1.35$ & Bare floor \\
\hline L102 & Lecture room 102 & Ground floor & $3.90 \times 1.50$ & Bare floor \\
\hline WSa & Workshop, main area & Ground floor & $1.50 \times 1.50$ & Bare floor \\
\hline WSb & Workshop, welding area & Ground floor & $1.50 \times 1.50$ & Bare floor \\
\hline C1 & $1^{\text {st }}$ floor corridor & 1st floor & $1.80 \times 3.00$ & Bare floor \\
\hline BC & Big Corridor & Ground floor & $2.70 \times 2.70$ & Bare floor \\
\hline
\end{tabular}


Table S3: Polycyclic aromatic hydrocarbons (PAHs [ng/g]) concentrations in the dust samples collected from the dwellings (Maragkidou et al., 2016).

\begin{tabular}{|l|c|r|r|r|r|r|r|r|r|r|r|r|r|r|}
\hline Location & Dwelling & PHE & ANT & FLA & PYR & BaA & CHR & BbF & BkF & BjF & BaP & IcdP & DahA & BghiP \\
\hline Entrance & DH2 & 498 & -- & 2037 & 354 & 44 & 191 & 324 & 90 & 90 & 23 & 46 & -- & 55 \\
\hline & A2 & 169 & -- & 147 & 157 & 65 & 104 & 116 & 67 & 51 & 64 & 60 & -- & 111 \\
\hline & DH3 & 241 & -- & 206 & 185 & 117 & 184 & 261 & 104 & 101 & 97 & 71 & 20 & 118 \\
\hline & DH4 & 1016 & 100 & 3879 & 997 & 114 & 530 & 308 & 113 & 94 & 45 & 52 & -- & 60 \\
\hline & A3 & 4973 & 806 & 2039 & 946 & -- & 51 & 26 & 24 & 11 & 10 & -- & 361 & 19 \\
\hline & A4 & 197 & -- & 110 & 89 & -- & 44 & 40 & 22 & 15 & 12 & 15 & -- & 26 \\
\hline & DH5 & 275 & -- & 261 & 211 & 59 & 110 & 72 & 42 & 25 & 33 & 31 & -- & 59 \\
\hline & H & 91 & -- & 53 & 47 & -- & 14 & 12 & 8 & 5 & -- & -- & -- & 11 \\
\hline & & & & & & & & & & & & & & \\
\hline Living Room & DH2 & 355 & -- & 138 & 122 & -- & 128 & 139 & 69 & 42 & -- & 39 & -- & 49 \\
\hline & A2 & 161 & -- & 65 & 67 & -- & 37 & 36 & 144 & -- & -- & -- & 172 & 27 \\
\hline & DH3 & 512 & 98 & 562 & 448 & 175 & 236 & 242 & 89 & 72 & 74 & 53 & -- & 76 \\
\hline & DH4 & 14413 & 2397 & 26630 & 15780 & 2184 & 2377 & 621 & 286 & 219 & 181 & 152 & -- & 181 \\
\hline & A3 & 1273 & 259 & 2454 & 1685 & 402 & 468 & 197 & 97 & 68 & 86 & 81 & 150 & 88 \\
\hline & A4 & 239 & -- & 91 & 84 & -- & 32 & 28 & 23 & 10 & 8 & -- & 107 & 20 \\
\hline & DH5 & 462 & -- & 153 & 118 & -- & 48 & 30 & 37 & 12 & 10 & -- & 37 & 24 \\
\hline & H & 197 & -- & 111 & 102 & -- & 42 & 32 & 24 & 13 & 9 & -- & 149 & 23 \\
\hline
\end{tabular}


Table S4: Polycyclic aromatic hydrocarbons (PAHs [ng/g]) concentrations in the dust samples collected from the educational building (Maragkidou et al., 2017).

\begin{tabular}{|c|c|c|c|c|c|c|c|c|c|c|c|c|c|c|}
\hline Location & & PHE & ANT & FLA & PYR & $\mathrm{BaA}$ & CHR & $\mathrm{BbF}$ & $\mathrm{BkF}$ & $\mathrm{BjF}$ & $\mathrm{BaP}$ & IcdP & DahA & BghiP \\
\hline Office & $\mathrm{P} 200$ & 380 & 168 & 810 & 672 & 487 & 763 & 603 & 258 & 241 & 222 & 241 & -- & 307 \\
\hline Office & P209 & 438 & 105 & 393 & 275 & 153 & 199 & 167 & 78 & 65 & 98 & 60 & -- & 94 \\
\hline Office & $\mathrm{P} 300$ & 410 & 106 & 969 & 723 & 467 & 739 & 693 & 241 & 220 & 253 & 174 & -- & 252 \\
\hline Office & $\mathrm{P} 303$ & 220 & 84 & 490 & 439 & 283 & 534 & 500 & 183 & 167 & 182 & 152 & -- & 210 \\
\hline Lecture room & L102 & 186 & 77 & 186 & 182 & 107 & 168 & 159 & 73 & 61 & 69 & 61 & 33 & 83 \\
\hline Lecture room & L230 & 316 & 99 & 264 & 243 & 141 & 199 & 212 & 86 & 68 & 101 & 83 & -- & 129 \\
\hline Workshop, main area & WSa & 171 & -- & 251 & 147 & -- & 147 & 270 & 32 & 81 & -- & 55 & -- & 93 \\
\hline Workshop, welding area & WSb & 190 & -- & 106 & 205 & -- & 43 & 38 & 14 & 14 & 22 & 19 & -- & 63 \\
\hline 1 st floor Corridor & $\mathrm{C} 1$ & 710 & 168 & 632 & 517 & 374 & 496 & 415 & 184 & 164 & 255 & 147 & 89 & 213 \\
\hline Big Corridor & $\mathrm{BC}$ & 471 & 74 & 519 & 489 & 224 & 334 & 262 & 110 & 96 & 137 & 77 & -- & 123 \\
\hline
\end{tabular}


1 Table S5: Microbe concentration [cell equivalent $/ \mathrm{mg}$ ] based on the qPCR-DNA analysis of the dust samples collected from the dwellings.

\begin{tabular}{|c|c|c|c|c|c|}
\hline Location & Dwelling & $\begin{array}{l}\text { Gram- } \\
\text { positive } \\
\text { bacteria }\end{array}$ & $\begin{array}{c}\text { Gram- } \\
\text { negative } \\
\text { bacteria }\end{array}$ & $\begin{array}{l}\text { Penicillium } \\
\text { Aspergillus } \\
\text { spp. }\end{array}$ & $\begin{array}{l}\text { Total } \\
\text { fungal }\end{array}$ \\
\hline \multirow[t]{8}{*}{ Entrance } & $\mathrm{DH} 2$ & ND & 1278700 & 600 & 14200 \\
\hline & $\mathrm{A} 2$ & 48200 & 1779800 & 7300 & 172300 \\
\hline & DH3 & 36700 & 246100 & 2600 & 10000 \\
\hline & DH4 & 29000 & 190500 & 1100 & 15300 \\
\hline & $\mathrm{A} 3$ & 348300 & 111300 & 1300 & 5700 \\
\hline & A4 & 17700 & 8900 & 200 & 500 \\
\hline & DH5 & 95800 & 478500 & 1900 & 16600 \\
\hline & $\mathrm{H}$ & $\mathrm{ND}$ & 2254200 & 5500 & 35100 \\
\hline \multirow[t]{8}{*}{ Living Room } & $\mathrm{DH} 2$ & NA & NA & NA & NA \\
\hline & $\mathrm{A} 2$ & 49700 & 57200 & 1300 & 1400 \\
\hline & DH3 & 173500 & 254900 & 3900 & 30200 \\
\hline & DH4 & 11300 & 351200 & 1100 & 4400 \\
\hline & $\mathrm{A} 3$ & 959100 & 423000 & 2000 & 7700 \\
\hline & A4 & 77200 & 20700 & 600 & 600 \\
\hline & DH5 & 174500 & 82900 & 5400 & 3700 \\
\hline & $\mathrm{H}$ & 265400 & 130900 & 26400 & 4200 \\
\hline
\end{tabular}


5 Table S6: Microbe concentration [cell equivalent $/ \mathrm{mg}$ ] based on the qPCR-DNA analysis of the dust samples 6 collected from the educational building.

\begin{tabular}{|c|r|r|r|r|r|}
\hline Location & \multicolumn{1}{|c|}{$\begin{array}{c}\text { Gram- } \\
\text { positive } \\
\text { bacteria }\end{array}$} & $\begin{array}{c}\text { Gram- } \\
\text { negative } \\
\text { bacteria }\end{array}$ & $\begin{array}{c}\text { Penicillium } \\
\text { Aspergillus } \\
\text { spp. }\end{array}$ & $\begin{array}{c}\text { Total } \\
\text { fungal }\end{array}$ \\
\hline Office & P200 & 46600 & 376000 & 600 & 3800 \\
\hline Office & P209 & 109300 & 315900 & 500 & 2700 \\
\hline Office & P300 & 20200 & 302600 & 600 & 3300 \\
\hline Office & P303 & 21300 & 288000 & 1500 & 7900 \\
\hline Lecture room & L102 & 44500 & 225600 & 1400 & 5100 \\
\hline Lecture room & L230 & 24700 & 195300 & 1100 & 7200 \\
\hline Workshop, main area & WSa & 8300 & 89700 & 700 & 2000 \\
\hline Workshop, welding area & WSb & 5300 & 38700 & 5100 & 700 \\
\hline 1st floor Corridor & $\mathrm{C} 1$ & 136000 & 124400 & 200 & 2700 \\
\hline Big Corridor & $\mathrm{BC}$ & 107400 & 495000 & 2300 & 10700 \\
\hline
\end{tabular}


9 Table S7: Spearmans correlation $(\rho)$ and p-value between the bacterial and fungal concentrations with the PAHs concentrations. The estimates in bold are considered statistically significant (or close to).

\begin{tabular}{|l|c|c|c|c|c|c|c|c|}
\hline & \multicolumn{2}{|c|}{$\begin{array}{c}\text { Gram-positive } \\
\text { bacteria }\end{array}$} & $\begin{array}{c}\text { Gram-negative } \\
\text { bacteria }\end{array}$ & \multicolumn{2}{c|}{$\begin{array}{c}\text { Penicillium } \\
\text { Aspergillus spp. }\end{array}$} & \multicolumn{2}{c|}{ Total fungal } \\
\hline & $\rho$ & p-value & $\rho$ & p-value & $\rho$ & p-value & $\rho$ & p-value \\
\hline Phenanthrene [PHE] & $\mathbf{0 . 4 8}$ & $\mathbf{0 . 0 4}$ & 0.15 & 0.52 & -0.37 & 0.10 & 0.10 & 0.67 \\
\hline Anthracene [ANT] & 0.07 & 0.88 & -0.08 & 0.84 & -0.80 & 0.01 & $\mathbf{- 0 . 6 8}$ & $\mathbf{0 . 0 5}$ \\
\hline Fluoranthene [FLA] & 0.09 & 0.72 & $\mathbf{0 . 4 3}$ & $\mathbf{0 . 0 5}$ & $\mathbf{- 0 . 4 1}$ & $\mathbf{0 . 0 7}$ & 0.26 & 0.26 \\
\hline Pyrene [PYR] & 0.00 & 0.99 & $\mathbf{0 . 3 9}$ & $\mathbf{0 . 0 8}$ & -0.31 & 0.17 & 0.21 & 0.36 \\
\hline Benz(a)anthracene [BaA] & -0.08 & 0.80 & -0.30 & 0.32 & -0.30 & 0.32 & $\mathbf{- 0 . 5 8}$ & $\mathbf{0 . 0 4}$ \\
\hline Chrysene [CHR] & -0.08 & 0.76 & 0.36 & 0.11 & -0.37 & 0.10 & 0.20 & 0.39 \\
\hline Benzo(b)fluoranthene [BbF] & -0.30 & 0.22 & 0.33 & 0.15 & $\mathbf{- 0 . 4 4}$ & $\mathbf{0 . 0 5}$ & 0.13 & 0.57 \\
\hline Benzo(k)fluoranthene [BkF] & 0.08 & 0.74 & 0.29 & 0.20 & -0.34 & 0.13 & 0.14 & 0.54 \\
\hline Benzo(j)fluoranthene [BjF] & -0.23 & 0.35 & 0.27 & 0.24 & $\mathbf{- 0 . 4 1}$ & $\mathbf{0 . 0 7}$ & 0.08 & 0.74 \\
\hline Benzo(a)pyrene [BaP] & -0.17 & 0.50 & 0.41 & 0.10 & -0.33 & 0.18 & 0.15 & 0.56 \\
\hline Indeno(1,2,3,c,d)pyrene [IcdP] & 0.12 & 0.68 & 0.20 & 0.45 & -0.15 & 0.57 & 0.06 & 0.82 \\
\hline Dibenz(a,h)anthracene [DahA] & 0.50 & 0.27 & -0.68 & 0.11 & -0.14 & 0.78 & $\mathbf{- 0 . 7 1}$ & $\mathbf{0 . 0 9}$ \\
\hline Benzo(g,h,i)perylene [BghiP] & -0.28 & 0.25 & 0.28 & 0.21 & -0.29 & 0.20 & 0.11 & 0.65 \\
\hline
\end{tabular}

11

12 

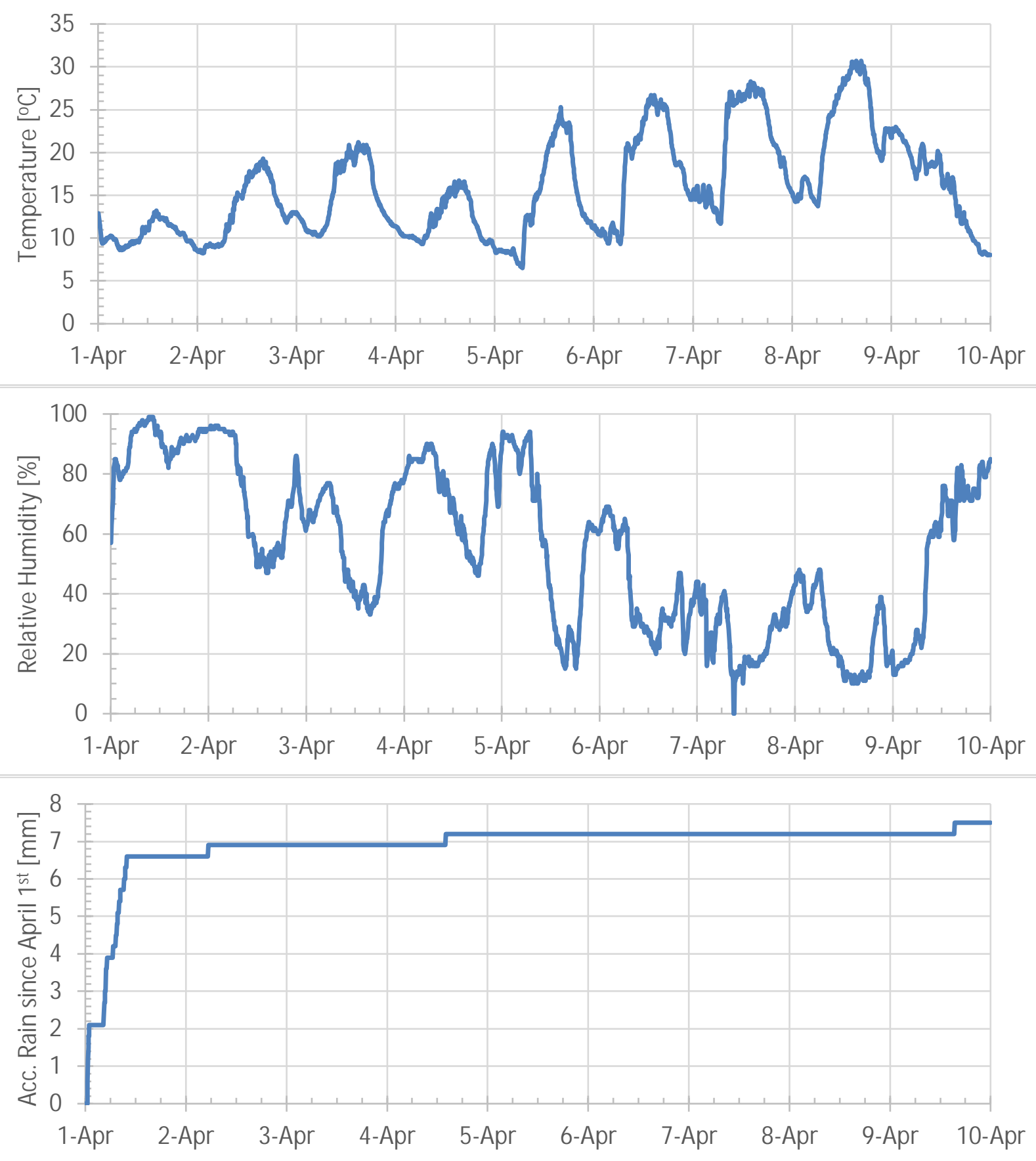

Figure S1: Ambient temperature, relative humidity, and accumulated rain (since April $1^{\text {st }}$ ). 


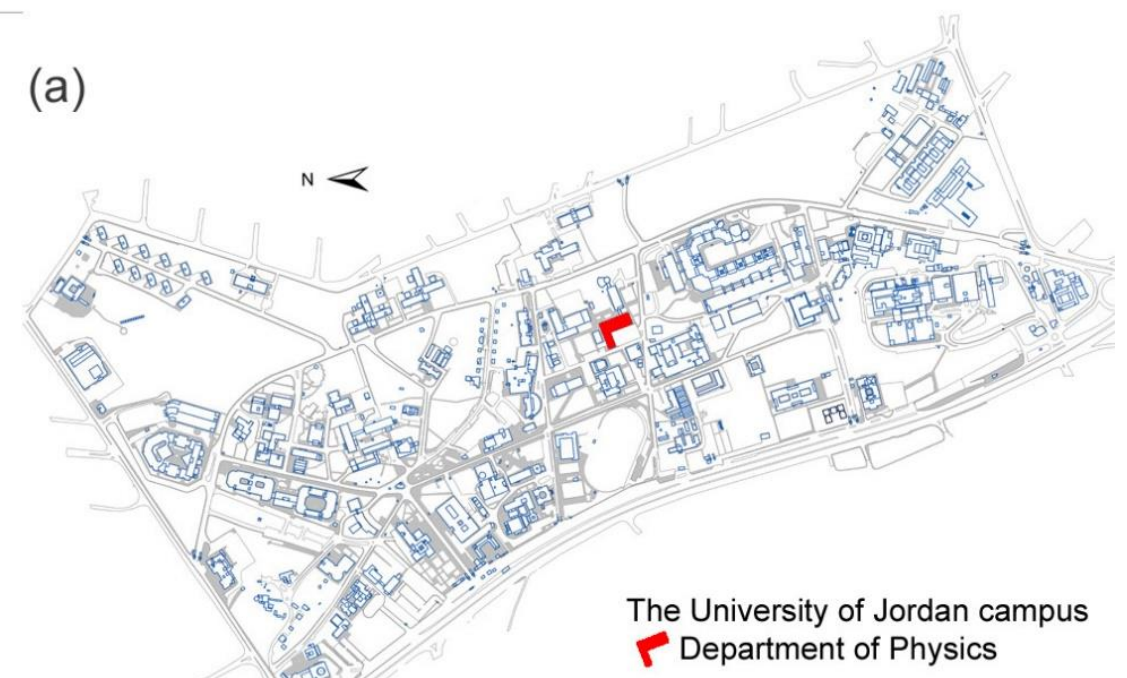

(b)

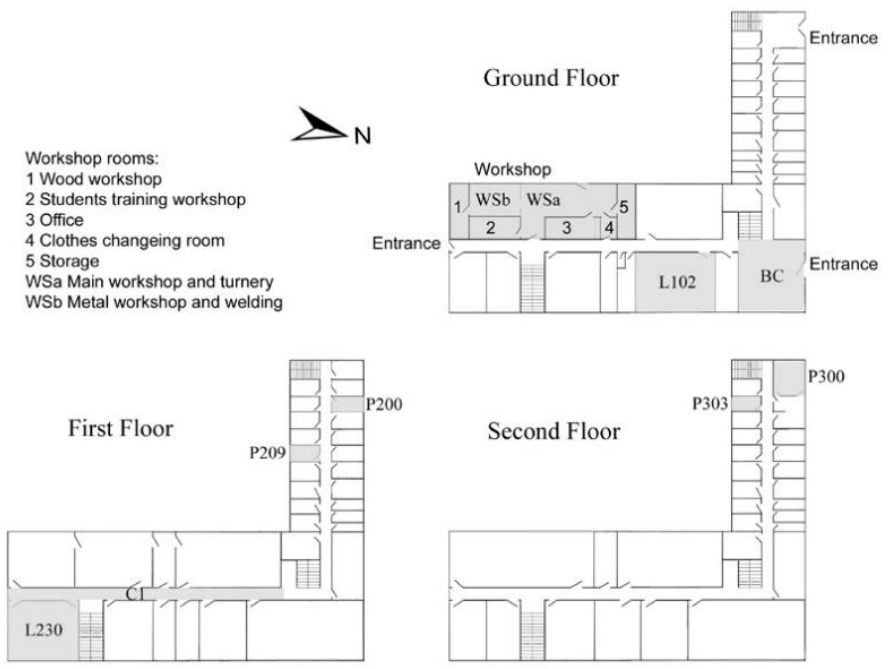

Figure S2: A map of the University of Jordan campus and a schematic chart of the Department of Physics with indications for the rooms from where floor dust samples were collected. 